\title{
Landslide hazard evaluation in and around the Ilam Hydropower Project, Eastern Nepal Himalaya
}

\author{
*Deepak Chamlagain and Vishnu Dangol \\ Department of Geology, Tri-Chandra Campus, Tribhuvan University, Ghantaghar, Kathmandu, Nepal \\ (*Corresponding author, e-mail: deepak@hotmail.com)
}

\begin{abstract}
The paper describes the results of the engineering geological and landslide hazard evaluation studies carried out in and around the Ilam Hydropower Project, eastern Nepal. Various types of mass wasting phenomena such as gully erosion, bank undercutting, and landslides are observed along the Mai Khola, Puwa Khola and road corridors. Gully erosion and bank undercutting are common on the slopes adjacent to streams and gullies. Most of the landslides are located on the slopes of $25^{\circ}$ to $40^{\circ}$ whereas large rock falls are found on the slopes, which are steeper than $40^{\circ}$. South-facing dip slopes contain large landslides while north-facing slopes seem to be relatively stable. The population of translational slide is dominant in the study area and is found mostly on soil having a depth of 3-6 m. Most of the rock falls are confined in schistose gneiss and highly fractured quartzite. Generally, three sets of joints govern the failure pattern of rockslides. The main triggering factors for mass movement of the area are high intensity of rainfail, rock discontinuities, steep topography, poor vegetation and river scouring. Land use pattern of the area has also equally contributed to initiate the mass movements in the area. The high hazard zones for rock slopes were confined to the steep dip slopes with highly fractured rocks whereas soi: slope hazard is confined to fault zones and south facing slope. The soil slope was found to be more hazardous than the rock slope. The main causative factors for the landslide hazard in the study area are steep slope, rock discontinuity, land use pattern, soil depth and rainfall.
\end{abstract}

\section{INTRODUCTION}

The study area lies in the central part of the Ilam District of Mechi Zone (Fig. 1). It is bounded by latitudes $26^{\circ} 51^{\prime} 30^{\prime \prime}$ $\mathrm{N}$ and $26^{\circ} 57^{\prime} 00^{\prime \prime} \mathrm{N}$ and longitudes $87^{\circ} 52^{\prime} 30^{\prime \prime} \mathrm{E}$ and $87^{\circ} 57^{\prime}$ 30 " E. It covers an area of about $40 \mathrm{sq}$. km. The elevation of the study area varies from $390 \mathrm{~m}$ to $1602 \mathrm{~m}$. The study area lies in subtropical climate zone and the total annual precipitation is about $1900 \mathrm{~mm}$ (DHM 1995/96).

This paper describes the effects of geology, geomorphology, soil type and depth, discontinuities, land use, hydrogeology to the slope instability and to prepare the landslide hazard map of the area. In this regard, various methods of landslide hazard mapping are reviewed and superimposition method was applied which is based on Deoja et al. (1991). For this method, different thematic maps were prepared. Then, base map was divided into several facets, which are restricted by ridges and rivers. The relative soil and rock slope hazard map was prepared by adding various rating values for soil and rock hazard components separately. The validity of the method was then checked by comparing the landslide hazard map with the actual distribution of landslides in the area. The method was found to be applicable in such geological and geomorphological setting.

\section{GEOLOGICAL SETTING}

The study area covers the southern part of the Higher Himalaya where the Higher Himalayan crystallines have been thrust over the Lesser Himalayan metasediments along the
MCT (Schelling 1992). Geology of the study area is dominated by the Precambrian to Cambrian kyanite and sillimanite bearing gneiss, biotite schist, metaquartzite, amphibolite, calcsilicate gneiss, orthogneiss and augen gneiss. The Mahabharat crystallines of the eastern Nepal are apparently continuous with the Darjeeling gneisses of the Sikkim Himalaya (Auden 1935, Gansser 1964).

The study area is a part of the basal and middle portion of the Mahabharat Crystallines, which is divisible into two subunits (Kayastha 1969 and Chamlagain 2000). Unit I consists of garnet-kyanite-sillimanite gneiss and grey

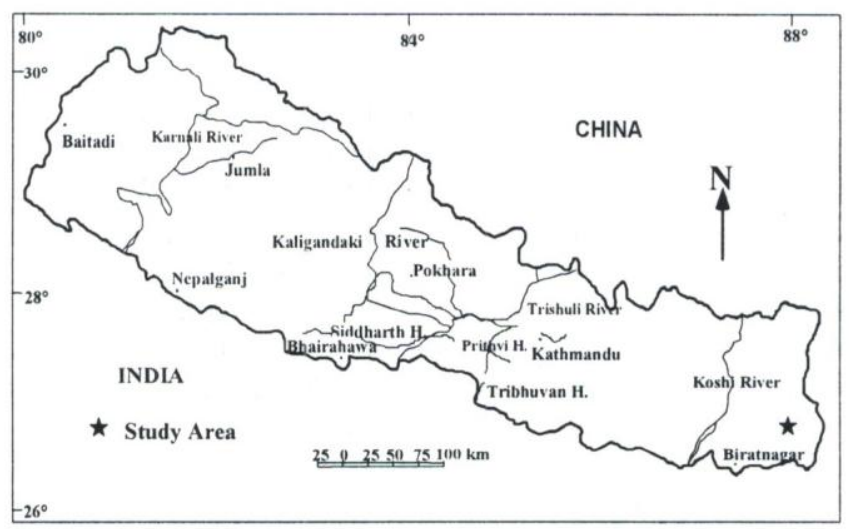

Fig. 1: Location map of the study area. 


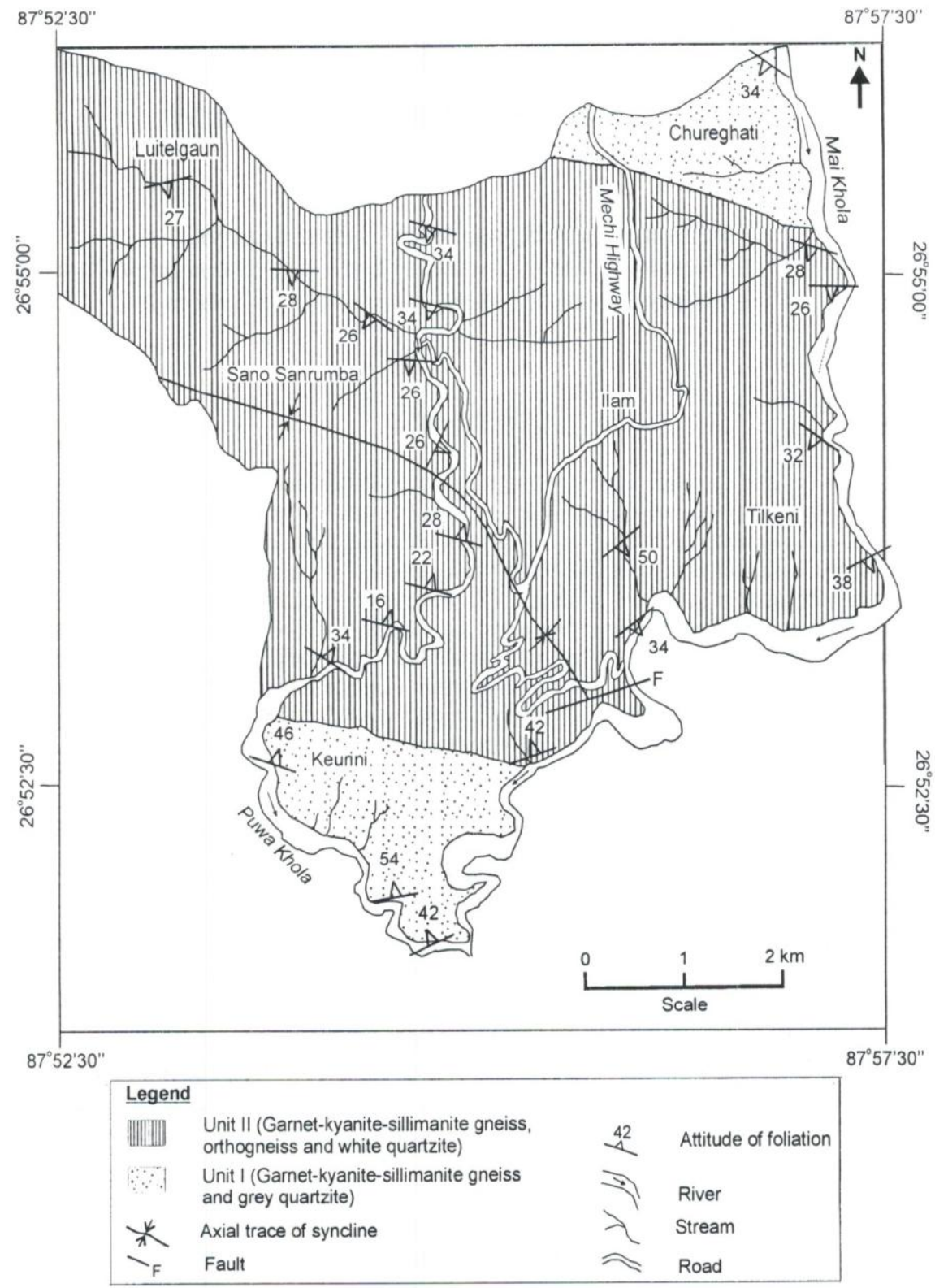

Fig. 2: Generalised geological map of the Ilam hydropower project and adjacent area.

quartzite, whereas Unit II is characterised by the presence of garnet-kyanite-sillimanite gneiss, orthogneiss and white coloured, coarse-grained, fractured quartzite (Fig. 2). Based on lithology and mineral paragenesis, the study area is comparable with Formation I of Le Fort (1975). The transformation of kyanite to sillimanite is conspicuous in thin section, which proves that the study area lies in transitional zone of kyanite and sillimanite isograd. Schelling and Arita (1991) also reported that the kyanite-sillimanite isograd lies between $5 \mathrm{~km}$ and $7 \mathrm{~km}$ above the MCT, which has proved by similar location of the study area. Synclinal structure is formed by the repetition of Unit I, garnetkyanite-sillimanite gnesiss and grey quartzite in the northern part. A local fault near the powerhouse site is observed which intersects the axis of syncline.

\section{GEOMORPHOLOGY}

The area is characterised by the varied topography. The slope angles of the area are divided into the following four categories: $0^{\circ}-15^{\circ}, 16^{\circ}-25^{\circ}, 26^{\circ}-40^{\circ}$ and $>40^{\circ}$ (Fig. 3). The landform is controlled mainly by tectonic processes and subordinately by mass wasting. The erosional landforms predominate over depositional ones. Rugged hills, numerous deep gorges along the Puwa Khola, steep slopes, quartzite cliffs and active gullies, e.g. the Narayanthan Kholsa and Chiyabari Kholsa, represent the erosional landforms. River terraces, alluvial fans along the Puwa Khola and Mai Khola, talus cones of various landslides are the main depositional landforms. The Mai Khola is the trunk river and its major tributaries are the Puwa Khola and Ghatte Khola. The Mai 


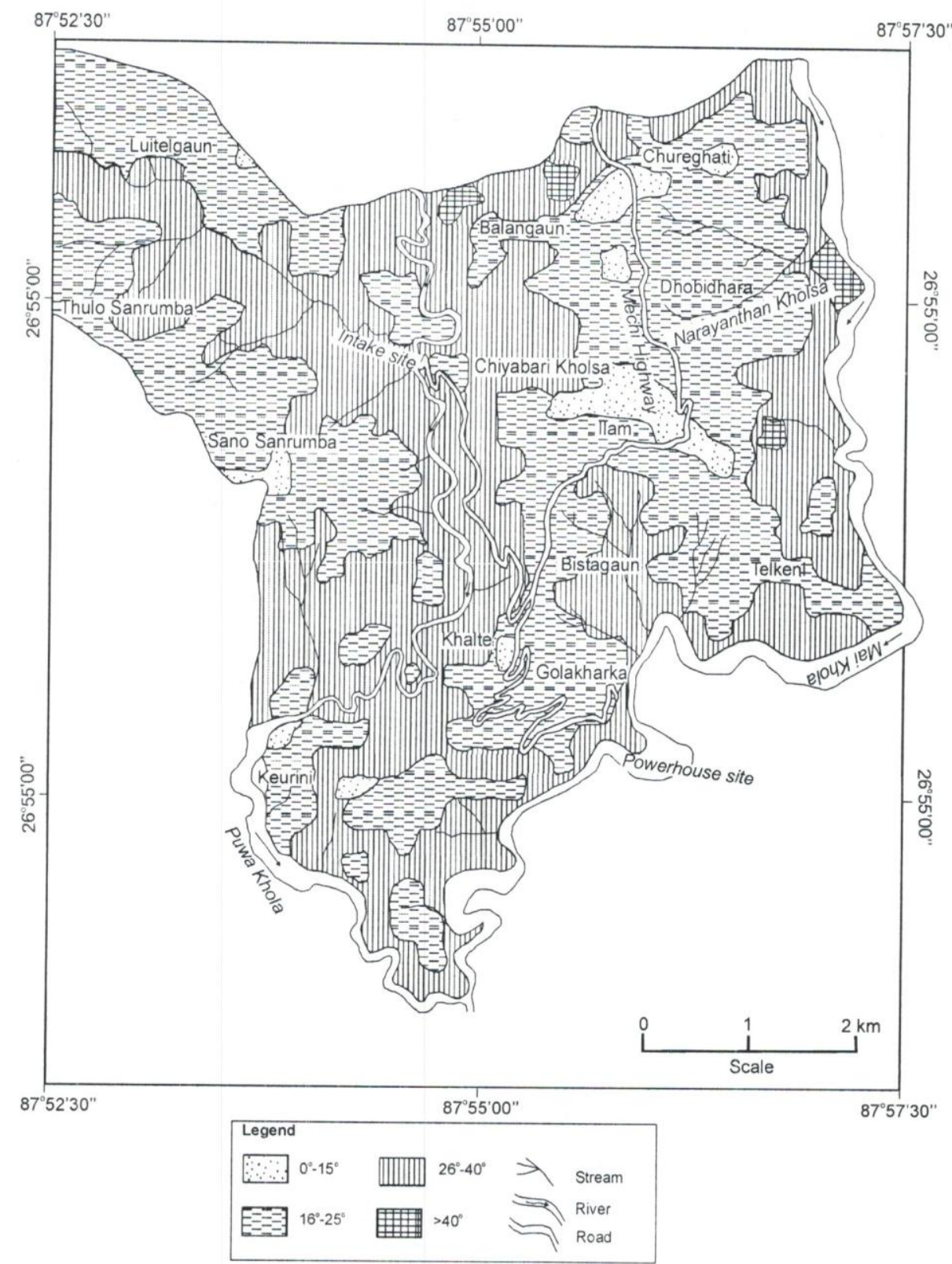

Fig. 3: Slope map of the Ilam hydropower project and adjacent area.

Khola and the Puwa Khola run due North-South and are more or less parallel to each other and join at Bhantar. Springs are frequently observed in fractured white quartzite. Subdendritic pattern is the common drainage pattern of the study area.

\section{ROCKS}

Medium- to coarse-grained white and grey quartzite, schistose gneiss and banded gneiss of the area have different strength characteristics. The effect of weathering is different in different rock types of the area. The degree of weathering is generally governed by frequency of discontinuity and mineralogical composition of rock. Schistose gneiss and banded gneiss are moderate to highly weathered (Grade IIIIV) but quartzite is slightly weathered (Grade- II) which is evident by slight discoloration of the surface. The schistose gneiss and banded gneiss are characterised by higher degree of weathering because feldspar content is high in it.

In analysing the stability of a rock slope, the most important factor to be considered is the geometry of rock mass behind the slope face. Geological structures such as bedding, joints, foliation, cleavage, schistosity and fault, are potentially weak planes. It is imperative to know their orientation in relation to slope angle, direction and strength along such potential weak planes. Keeping in mind the importance and influence of geological discontinuities on stability, rock mass was assessed on a larger scale (rock mass strength, with all its flaws) in order to evaluate its effect on slope stability. Table 1 shows the characteristics of rock mass of various locations. Schistose gneiss is 

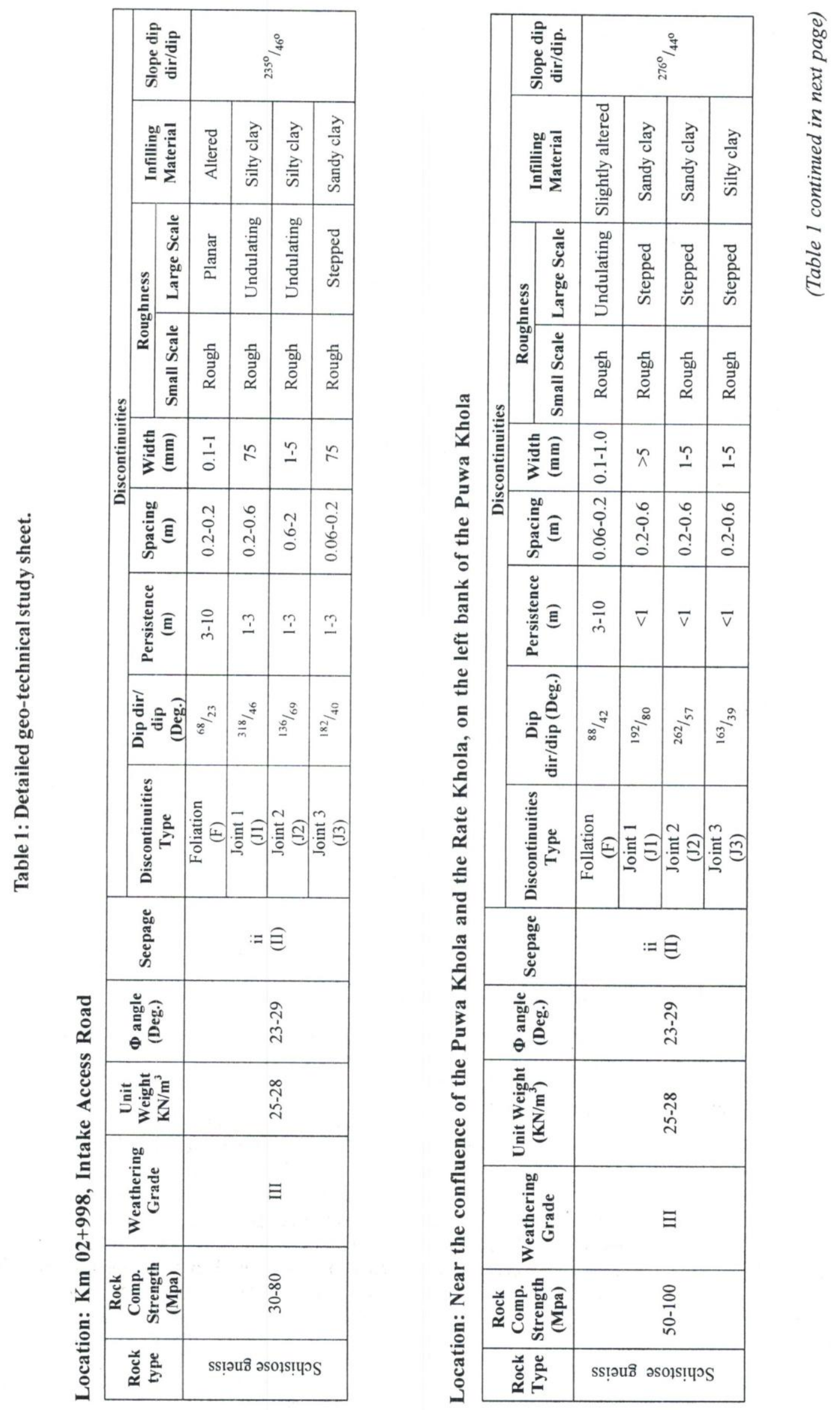
Landslide hazard evaluation in and around the Ilam Hydropower Project, Eastern Nepal

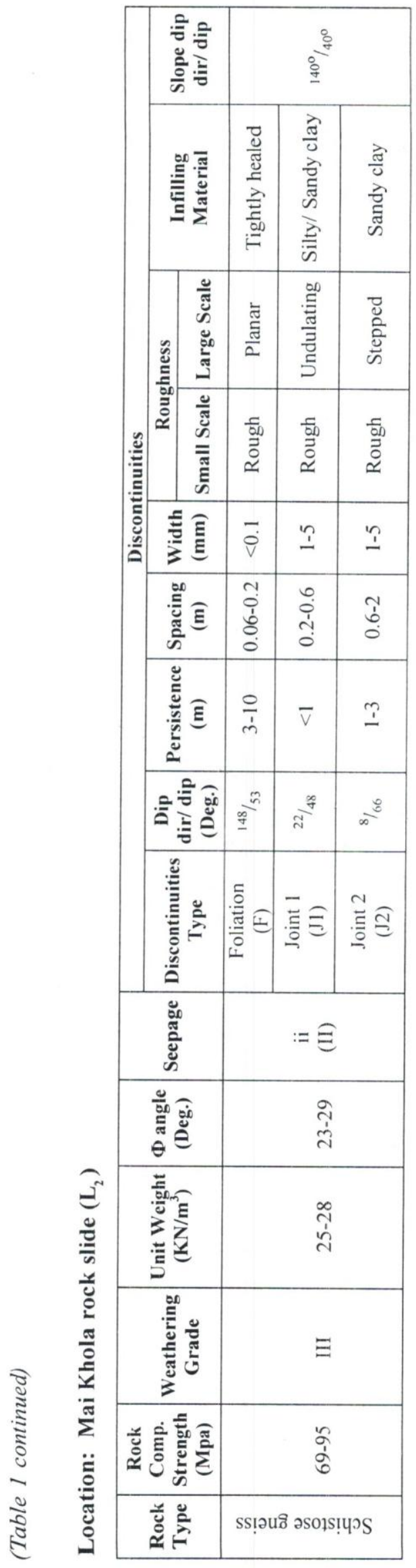

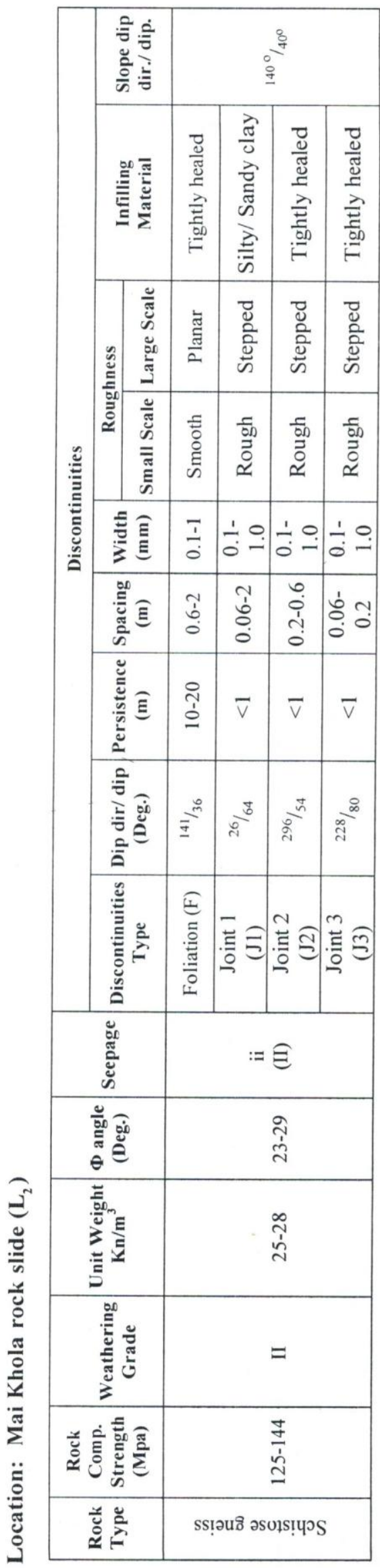


characterised by two to three sets of well-developed joints. Joint persistency varies from $<1 \mathrm{~m}$ to $3 \mathrm{~m}$, which are graded to very low persistence to low persistence. Whereas spacing varies from $6 \mathrm{~cm}$ to $2 \mathrm{~m}$ which grade rock mass as crush and scattered to massive. Joint surface is rough to stepped. Quartzites of the study area show quite different rock mass characteristics. Three sets of joints are prominently developed. On the basis of persistency, rock mass is classified as very low persistence and as fractured to massive rock mass on the basis of spacing. Joint surface roughness of quartzite varies from rough to stepped in small and large scale respectively. On the basis of above parameters, rock mass of the study area was classified as high, medium and low rock mass strength (Fig. 4).

Geometry of rock mass and natural hill slope govern the stability of rock slope. Statistical analysis of fourteen rock slopes carried out by using lower hemispherical projection (Fig. 4). In the intake site and south of Chiyabari Kholsa, central and lateral wedges are prominently developed but

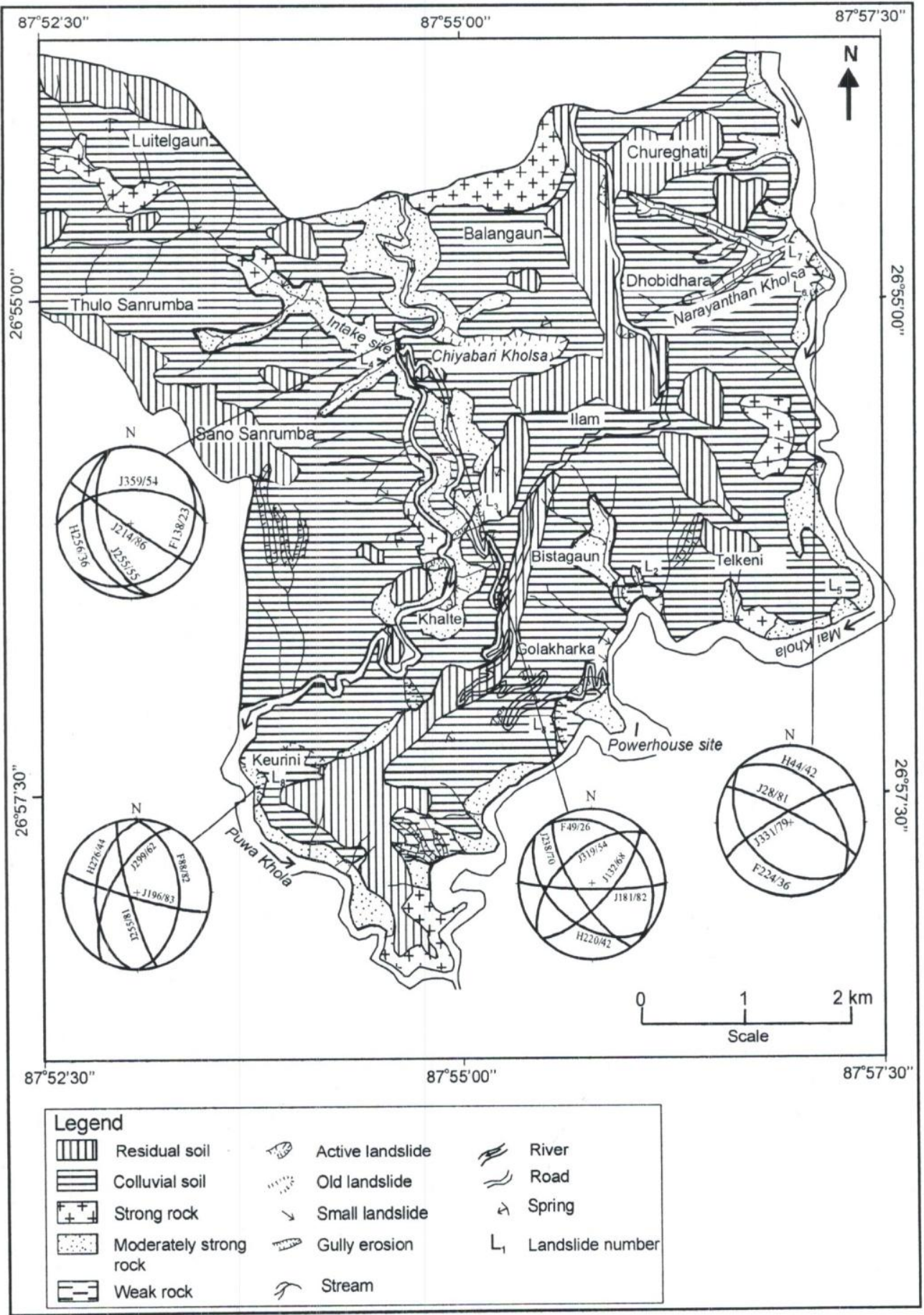

Fig. 4: Engineering geological map of the Ilam hydropower project and adjacent area. 
are not daylighted indicating stable rock s!opes. Similarly, the discontinuities at $\mathrm{L}_{1}$ form central wedge, which is not daylighted. Typical plane failure was observed at the location $\mathrm{L}_{2}$. Toppling failure observed in location $\mathrm{L}_{6}$ where foliation plane $\left(224^{\circ} / 36^{\circ}\right)$ dips at gentler than natural hill slopes $\left(044^{\circ} / 42^{\circ}\right)$ in opposite direction. The type and mode of failure are important to assess rock slope hazard. Thus the modes of failures were rated individually during the preparation of rock slope hazard map.

The Uniaxial Compressive Strength [UCS] and Uniaxial Tensile Strength [UTS] of intact rock samples (lump) from various locations were measured by point load test. The point load index corrected to a diameter of $50 \mathrm{~mm}$ [ $\left.\mathrm{I}_{\mathrm{s}}{ }_{50}\right]$, strength anisotropy index $\left(\mathrm{I}_{\mathrm{a}(50)}\right)$. The UCS and UTS values are presented in Table 2. There is considerable variation in strength parameter due to weathering and micro fracture present in rock samples. Coarse-grained white quartzite shows the highest uniaxial compressive strength, i.e. 144.48 Mpa perpendicular to anisotropy and $125.52 \mathrm{Mpa}$ parallel to anisotropy. But considerable reduction has been found in UCS values of banded gneiss (48-118 Mpa) and schistose gneiss (80-95 Mpa) due to effects of weathering as well as presence of micro-fracture in rock specimen. The obtained values of strength are very low for tested specimens, which might contribute for the instability of the area. Based on the strength parameter, rocks of the area were classified as strong, moderately strong and weak rock (Hoek and Bray 1977).

\section{SOILS}

Soil of the study area is classified according to their origin i.e. alluvial, colluvial and residual. Soil depth of the area is categorised as shallow (1-3 m), medium (3-6 m) and thick $(>6 \mathrm{~m})$.

\section{Residual soil}

Residual soils are extensively distributed on moderate to gentle slopes, along ridge and spurs i.e. Keurini, Golakharka Bhanjyang, Bistagaon, Ilam Bazar, Godithumka, Chureghati, South-East of the Thulo Sanrumba (Fig. 4). The shallow (1-3 m) residual soils are distributed on moderate steep slopes below ridges and spurs. The residual soils having medium depth (3-6 m) are extensively distributed around north of Sano Sanrumba, Ilam Bazar, around Keurini and south of the Golakharka Bhanjyan. The thick (>6 m) soils are sparsely distributed around Sano Sanrumba, SouthWest of Golakharka Bhanjyan and Ilam Bazar. The soil ranges in size from clayey silt to sandy clayey silt with some coarse particles.

\section{Colluvial Soils}

Colluvial soils are predominantly distributed in the study area. They are observed around Luitelgaon North-East of Thulo Sanrumba, Sano Sanrumba, Golakharka, Keurini etc. and are basically tallus deposits (Fig. 4) which are shallow in

Table 2: Result of point load test of rock samples.

\begin{tabular}{|c|c|c|c|c|c|c|c|}
\hline $\begin{array}{c}\text { Sample } \\
\text { No. }\end{array}$ & Location & Rock Type & Test & $\begin{array}{c}\text { Mean } \\
\mathbf{I}_{\mathrm{s}(50)} \\
\end{array}$ & $\begin{array}{l}\mathrm{UCS} \\
\text { (Mpa) }\end{array}$ & $\mathbf{I}_{\mathbf{a}(\mathbf{5 0 )}}$ & $\begin{array}{l}\text { UTS } \\
\text { (Mpa) }\end{array}$ \\
\hline \multirow{2}{*}{$\mathrm{R}_{1}$} & \multirow{2}{*}{$\begin{array}{c}\mathrm{Km} 01+534 \\
\text { (Intake Access Road) }\end{array}$} & \multirow{2}{*}{$\begin{array}{l}\text { Coarse-grained, } \\
\text { White quartzite }\end{array}$} & $\perp$ & 2.95 & 70.80 & 1.20 & 3.68 \\
\hline & & & $\|$ & 2.45 & 58.80 & & 3.06 \\
\hline \multirow{2}{*}{$\mathrm{R}_{2}$} & \multirow{2}{*}{$\begin{array}{c}\mathrm{Km} 02+024 \\
\text { (Intake Access Road) }\end{array}$} & \multirow{2}{*}{ Banded gneiss } & $\perp$ & 6.03 & 144.72 & 1.32 & 7.53 \\
\hline & & & $\|$ & 4.58 & 109.90 & & 5.72 \\
\hline \multirow{2}{*}{$\mathrm{R}_{3}$} & \multirow{2}{*}{$\begin{array}{c}\mathrm{Km} 02+084 \\
\text { (Intake Access Road) }\end{array}$} & \multirow{2}{*}{$\begin{array}{c}\text { Quartzite } \\
\text { (Weathered) }\end{array}$} & $\perp$ & 4.04 & 96.96 & 1.31 & 5.05 \\
\hline & & & $\|$ & 3.08 & 73.92 & & 3.85 \\
\hline \multirow{2}{*}{$\mathrm{R}_{4}$} & \multirow{2}{*}{$\begin{array}{c}\mathrm{Km} 02+110 \\
\text { (Intake Access Road) }\end{array}$} & \multirow{2}{*}{ Quartzite } & $\perp$ & 5.89 & 141.36 & 1.51 & 7.36 \\
\hline & & & $\|$ & 3.90 & 93.60 & & 4.87 \\
\hline \multirow{2}{*}{$\mathrm{R}_{5}$} & \multirow{2}{*}{$\begin{array}{c}\mathrm{Km} 02+998 \\
\text { (Intake Access Road) }\end{array}$} & \multirow{2}{*}{ Schistose gneiss } & $\perp$ & 3.33 & 79.92 & 2.66 & 4.16 \\
\hline & & & $\|$ & 1.25 & 30.00 & & 1.56 \\
\hline \multirow{2}{*}{$\mathrm{R}_{6}$} & \multirow{2}{*}{$\begin{array}{c}\mathrm{Km} 03+018 \\
\text { (Intake Access Road) }\end{array}$} & \multirow{2}{*}{$\begin{array}{l}\text { Banded gneiss } \\
\text { (Weathered) }\end{array}$} & $\perp$ & 3.38 & 81.12 & 1.07 & 4.22 \\
\hline & & & $\|$ & 3.16 & 75.84 & & 3.95 \\
\hline \multirow{2}{*}{$\mathrm{R}_{7}$} & \multirow{2}{*}{$\begin{array}{c}\text { Km 03+080 } \\
\text { (Powerhouse Access Road) }\end{array}$} & \multirow{2}{*}{ Schistose gneiss } & $\perp$ & 3.39 & 94.32 & 4.79 & 4.91 \\
\hline & & & $\|$ & 0.82 & 19.68 & & 1.02 \\
\hline \multirow{2}{*}{$\mathrm{L}_{8}$} & \multirow{2}{*}{$\begin{array}{l}\text { Mail Khola } \\
\text { Rock slide }\end{array}$} & \multirow{2}{*}{$\begin{array}{l}\text { Coarse-grained } \\
\text { White quartzite }\end{array}$} & $\perp$ & 6.02 & 144.48 & 1.15 & 7.52 \\
\hline & & & $\|$ & 5.23 & 125.52 & & 6.53 \\
\hline \multirow{2}{*}{$\mathrm{L}_{8}$} & \multirow{2}{*}{$\begin{array}{l}\text { Mai Khola } \\
\text { Rock slide }\end{array}$} & \multirow{2}{*}{ Banded gneiss } & $\perp$ & 4.92 & 118.08 & 3.54 & 6.15 \\
\hline & & & $\Perp$ & 1.39 & 33.36 & & 1.74 \\
\hline \multirow{2}{*}{$\mathrm{L}_{8}$} & \multirow{2}{*}{$\begin{array}{l}\text { Mai Khola } \\
\text { Rock Slide }\end{array}$} & \multirow{2}{*}{ Schistose gneiss } & $\perp$ & 3.95 & 94.80 & 1.37 & 4.94 \\
\hline & & & $\Perp$ & 2.88 & 69.12 & & 3.60 \\
\hline \multirow{2}{*}{$\mathrm{L}_{8}$} & \multirow{2}{*}{$\begin{array}{l}\text { Mai Khola } \\
\text { Rock Slide }\end{array}$} & \multirow{2}{*}{$\begin{array}{l}\text { Banded gneiss } \\
\text { (Weathered) }\end{array}$} & $\perp$ & 2.01 & 48.24 & 1.08 & 2.51 \\
\hline & & & $\|$ & 1.86 & 44.64 & & 2.32 \\
\hline
\end{tabular}

$\perp=$ Perpendicular to anisotropy $\quad \|=$ Parallel to anisotropy 
depth at the upper slopes and thick in the foothills. Colluvial soils are composed of angular to subangular clasts of schist, gneiss and quartzite.

\section{LAND USE}

Owing to the varied land structure, the land use pattern of the area is diverse. The land use pattern of the area is classified as forest, barren land, dry cultivated land, wet cultivated land, tea estate, shrub land, and settlement area (Table 3). In the study area, conversion of the forest land to cultivable land is being accelerated due to population growth. About $62 \%$ land is cultivated. Dry cultivated land is extensively distributed in the eastern and western slopes whereas wet cultivated land is distributed in the central part of the study area. Other parts of the area and rocky terrain are covered by forest and shrub land.

\section{LANDSLIDE}

Landslides were studied on the basis of aerial photographs and topographic map combined with field investigations, which revealed that about $6 \%$ of the total area, has been affected by landslide activities. The rainstorm of 1997 triggered off most of the slope failures. Mass wasting phenomena such as rock fall, rock topple, rotational slide, translational slide and gully erosion are observed in the study area. Translational slides are more common in the area (Fig. 5). In the study area, the population of wedge failure is the highest as compared to toppling and plane failure. Large landslides are especially common on south facing dip-slope but north-facing slope is more stable. Table 4 summarizes types, features and triggering factors of major landslides in the study area.

Table 5 shows the location of various types of landslides found in different slope categories. The distribution of landslides with respect to slope (Fig. 6) reveals that the maximum landslide is found in areas having slope angle between $26^{\circ}$ and $40^{\circ}$. This appears due to the proximity of this hill face, in general, to the middle and upper part of slopes, which are characterised by shrub land and barren land. The slope failure activities are also conspicuous in areas characterised by moderate slope angle between $16^{\circ}$ and $25^{\circ}$. The slope failures associated with this slope classes have also relation with the land use pattern. The distribution of landslides in relation to the land use pattern (Fig. 7) indicates that the most of slope movements occurred in shrub land (34.29\%) and barren land $(22.85 \%)$, and least in dry cultivated land $(11.43 \%)$.

Most of the rockslides, rock falls and topples are common on the southeast facing slopes. Shallow slides, gully erosion and small soil slides are observed on counter dip slopes. The large deep-seated soil slides occurred in deeply weathered soil whose depth ranges from 1 to $6 \mathrm{~m}$. Many tension cracks were observed at the vicinity of crown of the slides especially in landslides along the Mechi Highway $\left(\mathrm{L}_{8}\right)$, intake access road $\left(\mathrm{L}_{3}\right)$ etc. In the study area, most of landslides occur in soil and the least in rock (Fig. 8).

The major structural features present in the area are a syncline and a fault. The axis of the syncline passes through Thulo Sanrumba, Sano Sanrumba, Khalte and Golakharka. A local fault passes near by powerhouse, intersects syncline, disrupting its axis in the eastern part of the study area (Chamlagain 2000). The area around these structures is characterised by large rockslide and deep soil slides. Besides this area, landslides are found wherever the discontinuity surfaces like joints and bedding planes are day lighted on the slopes.

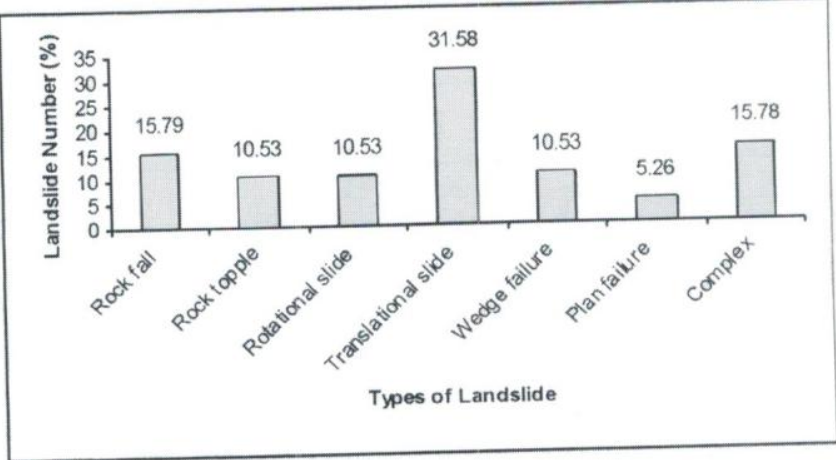

Fig. 5: Distribution of different types of landslides in the area.

Table 3: Summary of land use pattern.

\begin{tabular}{|l|c|c|l|}
\hline \multicolumn{1}{|c|}{ Land use pattern } & Area (Sq. km.) & Percentage & \multicolumn{1}{c|}{ Remarks } \\
\hline Forest & 9.65 & 24.23 & $\begin{array}{l}\text { Minor gully erosion but densely forested } \\
\text { area are relatively safe }\end{array}$ \\
\hline Barren land & 1.51 & 3.97 & $\begin{array}{l}\text { Many small and medium landslides (rock } \\
\text { fall) and severely developed gully erosion }\end{array}$ \\
\hline Dry cultivated land & 19.5 & 48.97 & $\begin{array}{l}\text { Many rills and gully erosion and } \\
\text { landslides }\end{array}$ \\
\hline Wet cultivated land & 4.66 & 11.70 & Gully erosion and medium landslide \\
\hline Tea estate & 0.47 & 1.18 & Small rill and gully erosion \\
\hline Shrub land & 3.02 & 7.58 & Several gully and rill erosion \\
\hline Settlement & 1.01 & 2.54 & Mostly safe area \\
\hline Total & 39.82 & 100.00 & \\
\hline
\end{tabular}


Table 4: Features and triggering factors for major landslides.

\begin{tabular}{|c|c|l|l|l|l|}
\hline $\begin{array}{c}\text { Volume of } \\
\left.\text { landslide } \mathbf{~ m}^{\mathbf{3}}\right)\end{array}$ & $\begin{array}{c}\text { Landslide } \\
\text { No. }\end{array}$ & \multicolumn{1}{|c|}{ Type } & \multicolumn{1}{|c|}{ Failure pattern } & \multicolumn{1}{|c|}{ Slide material } & \multicolumn{1}{|c|}{ Triggering factors } \\
\hline 39375 & $\mathrm{~L}_{1}$ & Rock topple & $\begin{array}{l}\text { Planar (mainly) } \\
\text { toppling and rock fall in } \\
\text { schistose gneiss and } \\
\text { quartzite }\end{array}$ & $\begin{array}{l}\text { Schistose gneiss } \\
\text { and quartzite }\end{array}$ & $\begin{array}{l}\text { Rainfall, pore water pressure, river } \\
\text { scouring, fracturing of schistose gneiss } \\
\text { and quartzite }\end{array}$ \\
\hline 37500 & $\mathrm{~L}_{2}$ & $\begin{array}{l}\text { Rock slide } \\
\text { (Plane failure) }\end{array}$ & $\begin{array}{l}\text { Planar (Mainly wedge } \\
\text { failure in white } \\
\text { quartzite and schistose } \\
\text { gneiss }\end{array}$ & $\begin{array}{l}\text { Schistose gneiss } \\
\text { and quartzite }\end{array}$ & $\begin{array}{l}\text { Fracturing of quartzite and schistose } \\
\text { gneiss, river scouring, rainfall }\end{array}$ \\
\hline 70312 & $\mathrm{~L}_{3}$ & $\begin{array}{l}\text { Rotational } \\
\text { slide }\end{array}$ & Circular & $\begin{array}{l}\text { Colluvial soil and } \\
\text { broken rock }\end{array}$ & $\begin{array}{l}\text { Excavation, pore water pressure, } \\
\text { rainfall }\end{array}$ \\
\hline 14500 & $\mathrm{~L}_{4}$ & Rock fall & Wedge failure & $\begin{array}{l}\text { Schistose gneiss } \\
\text { and quartzite }\end{array}$ & $\begin{array}{l}\text { Steep slope, discontinuities, river } \\
\text { scouring pore water pressure }\end{array}$ \\
\hline 34500 & $\mathrm{~L}_{5}$ & Rock fall & Wedge failure toppling & Schistose gneiss & $\begin{array}{l}\text { Steep slope, discontinuities, pore water } \\
\text { pressure }\end{array}$ \\
\hline 16500 & $\mathrm{~L}_{6}$ & Rock fall & Wedge failure toppling & $\begin{array}{l}\text { Fragments of } \\
\text { quartzite }\end{array}$ & $\begin{array}{l}\text { Steep slope, discontinuities, pore water } \\
\text { pressure, poor vegetation, river } \\
\text { scouring }\end{array}$ \\
\hline 3400 & $\mathrm{~L}_{7}$ & Rock topple & Toppling, wedge failure & $\begin{array}{l}\text { Fragments of } \\
\text { schistose gneiss, }\end{array}$ & $\begin{array}{l}\text { Rock discontinuities pore water } \\
\text { pressure river scouring rainfall, poor } \\
\text { vegetation }\end{array}$ \\
\hline
\end{tabular}

Table 5: Distribution of landslides in different slope categories.

\begin{tabular}{|c|l|l|}
\hline $\begin{array}{c}\text { Slope } \\
\text { Categories }\end{array}$ & \multicolumn{1}{c|}{ Location } & \multicolumn{1}{c|}{ Remark } \\
\hline $0^{\circ}-15^{\circ}$ & $\begin{array}{l}\text { Ilam Bazar, Gadithumka, east of Chureghati, } \\
\text { Khalte, S-E of Sano Sanrumba and West of } \\
\text { Gewadanda }\end{array}$ & $\begin{array}{l}\text { Many small landslides and severely developed gully } \\
\text { erosion }\end{array}$ \\
\hline $16^{\circ}-25^{\circ}$ & $\begin{array}{l}\text { Around Gewadanda, Puwajun, Golakharka, } \\
\text { Tilkenimod, Dhobidhara, Chureghati, Luitelgon and } \\
\text { Gairigaon }\end{array}$ & $\begin{array}{l}\text { Small landslides and moderately developed gullies in } \\
\text { sparsely vegetated area }\end{array}$ \\
\hline $26^{\circ}-40^{\circ}$ & $\begin{array}{l}\text { Along the Puwa Khola, Right bank of the Mai } \\
\text { Khola, Ghatte Khola, Keurini, Balangaon }\end{array}$ & $\begin{array}{l}\text { Large soilslides and small rock falls. It is highly } \\
\text { hazardous zone }\end{array}$ \\
\hline$>40^{\circ}$ & East of Tilkenimod, northeast of Mahabhir & $\begin{array}{l}\text { Rock falls and medium landslide, very hazardous slope } \\
\text { and many large rock falls }\end{array}$ \\
\hline
\end{tabular}

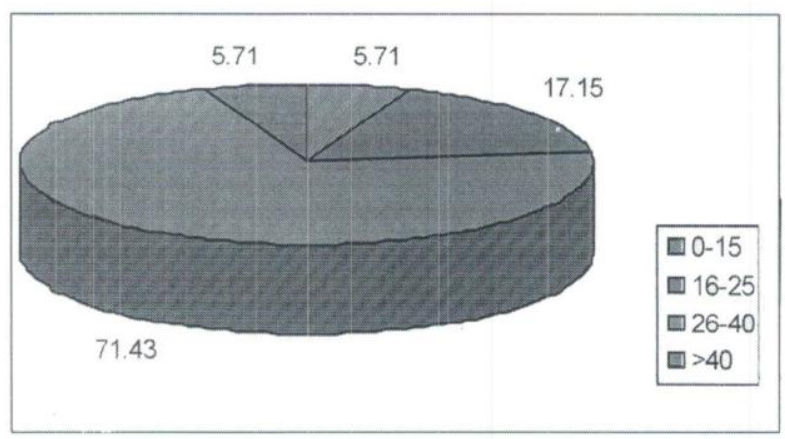

Fig. 6: Occurrence of landslides in various slopes (degree).

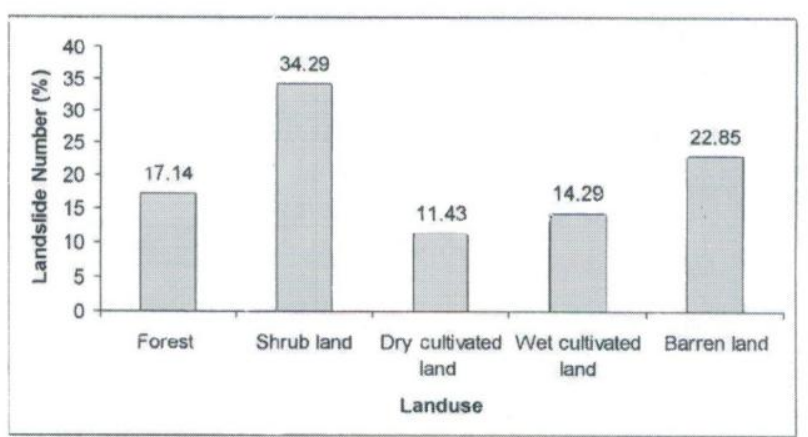

Fig. 7: Distribution of the landslides in relation to land use pattern. 


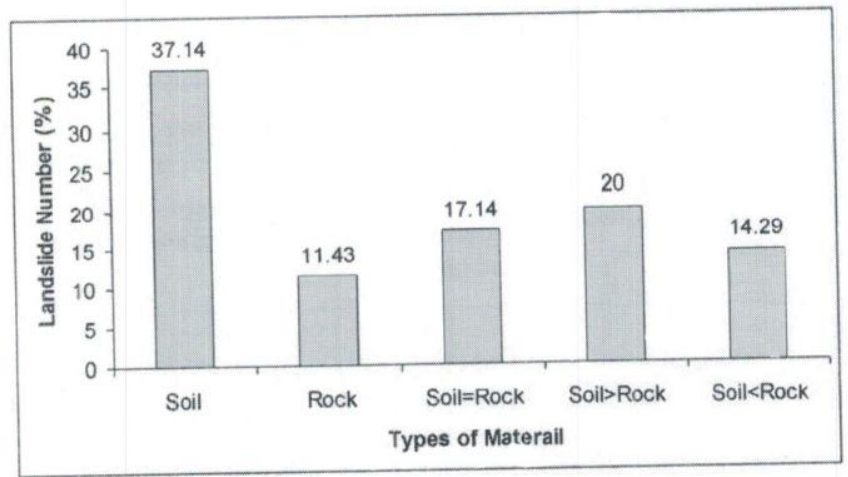

Fig. 8: Types of material involved in the landslides.

\section{LANDSLIDE HAZARD ZONATION MAPPING}

Landslide hazard mapping invokes a multidisciplinary approach, integrating all the influencing factors on slope instability in the study area (Uromeihy 2000). Various methods for hazard mapping have been developed in recent years. In this study, superposition method developed by Deoja et al. (1991) was used. During the investigation, various hazard attributes like structural component, geomechanical component, hydrogeological component, seismotectonic component, soil type versus slope component, soil depth component, hydrodynamic component, land use component and landslide and gully erosion component were identified and their contribution to the landslide hazard was assessed. Different thematic maps (soil type and depth, slope, land use, morphostructural, hydrogeological, engineering geological and landslide distribution map) based on hazard components were prepared. Then, base map was divided into several slope facets, which are restricted by ridges and rivers. The relative hazard map at 1:25,000 scales was prepared by adding ratings for various hazard components. The area covered by soil and rocks were rated separately using superimposition method. The main influencing factors for soil and rock slope hazards and their ratings are summarized in Table 6 and 7.

\section{Classification of hazard level}

The rock and soil hazard levels were classified into low, medium and high depending upon the total rating values of different hazard components (Table 8).

Among the various level of hazards, the areas of low hazard are considered to be more or less safe zones where

Table 6: Soil slope hazard rating (modified from Deoja et al. 1991).

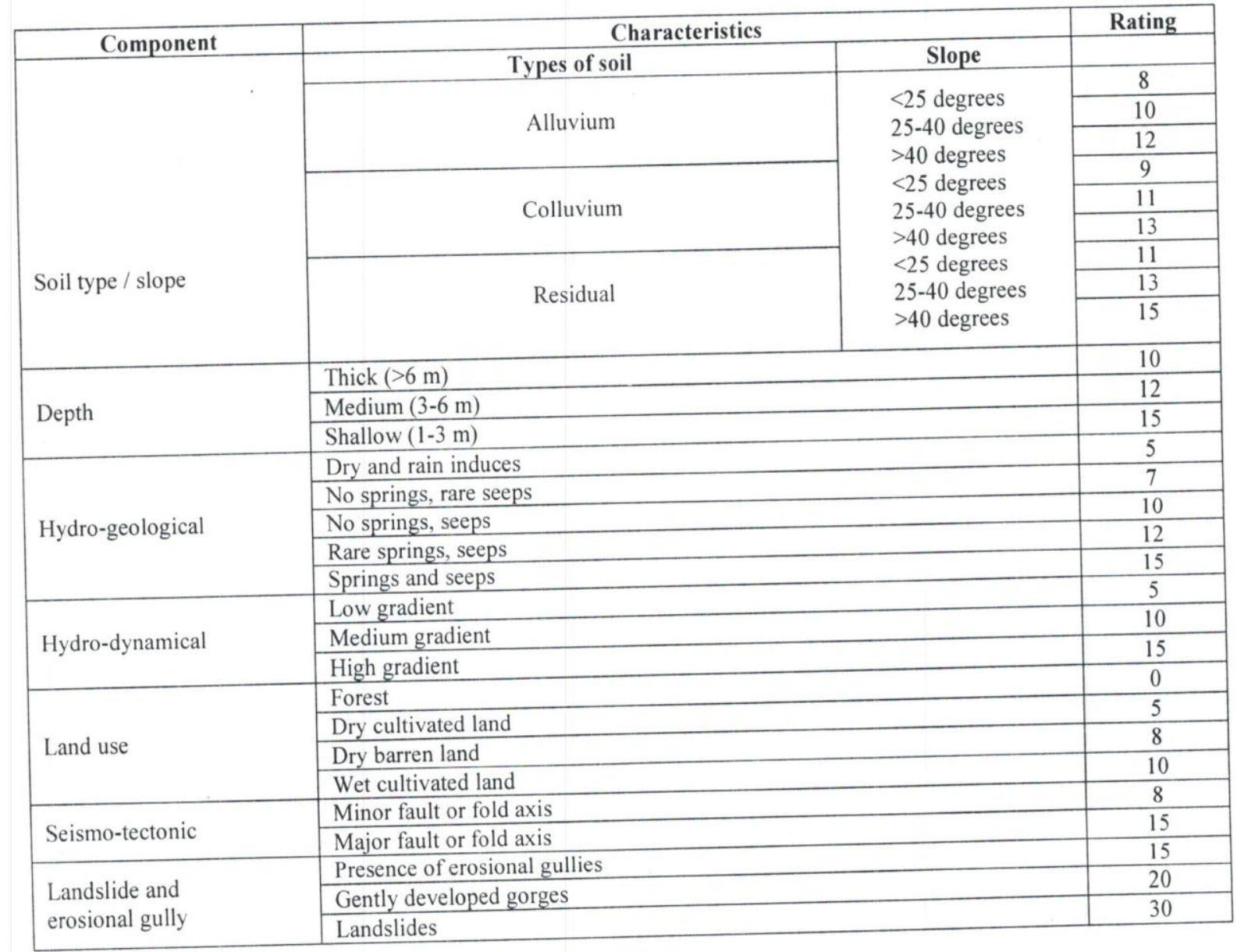


normally no natural disaster occurs. The medium hazard region can be made safe and stable with mitigating measures. But high hazard zones are difficult to stabilise and sometimes impossible too. It is better to avoid for the construction of large infrastructure, settlement and cultivation.

\section{Description of main hazardous areas}

Various levels of hazard and their location are shown in Fig. 9. The most hazardous zones in the study area lie along the Puwa Khola, Mai Khola and in the active gullies. The main causative factors for landslide hazard in the study area are steep slope, rock discontinuity, land use pattern, soil depth and hydro-geological condition. High hazard zones are confined near Sanrumba, Luitelgaun, Keurini, Golakharka, Powerhouse site and Mahabhir north of Dhobidhara etc. Medium hazard zones are confined around Luitelgaun, Tilkenimod, Bistagaon. The remaining parts of the study area lie in low rock and soil hazard.

Table 8: Hazard level classification.

\begin{tabular}{|l|l|}
\hline \multicolumn{1}{|c|}{ Hazard level } & \multicolumn{1}{c|}{ Total rating } \\
\hline Low & $<40$ \\
\hline Medium & $40-65$ \\
\hline High & $>65$ \\
\hline
\end{tabular}

Table 7: Rock slope hazard rating (modified from Deoja et al. 1991).

\begin{tabular}{|c|c|c|c|c|c|}
\hline \multirow{3}{*}{ Component } & \multicolumn{4}{|c|}{ Characteristics } & \multirow[t]{3}{*}{ Rating } \\
\hline & \multicolumn{4}{|c|}{ Expected mode of failure } & \\
\hline & $\begin{array}{c}\text { General wedges } \\
\text { (number) }\end{array}$ & $\begin{array}{c}\text { Lateral wedges } \\
\text { (number) }\end{array}$ & Plane failure & Topple slope $>60$ degree & \\
\hline \multirow{19}{*}{ Structural } & 0 & 0 & 0 & 1 & 5 \\
\hline & 0 & 1 & 0 & $0 / 1$ & 7 \\
\hline & 0 & $>1$ & 0 & $0 / 1$ & 14 \\
\hline & 0 & 0 & 1 & $0 / 1$ & 10 \\
\hline & 0 & 1 & 1 & $0 / 1$ & 17 \\
\hline & 0 & $>1$ & 1 & $0 / 1$ & 23 \\
\hline & 1 & 0 & 0 & $0 / 1$ & 15 \\
\hline & 1 & 0 & 0 & $0 / 1$ & 21 \\
\hline & 1 & $>1$ & 0 & $0 / 1$ & 27 \\
\hline & 1 & 0 & 1 & $0 / 1$ & 25 \\
\hline & 1 & 1 & 1 & $0 / 1$ & 28 \\
\hline & 1 & $>1$ & 1 & $0 / 1$ & 34 \\
\hline & $>1$ & 0 & 0 & $0 / 1$ & 21 \\
\hline & $>1$ & 1 & 0 & $0 / 1$ & 27 \\
\hline & $>1$ & $>1$ & 0 & $0 / 1$ & 33 \\
\hline & $>1$ & 0 & 1 & $0 / 1$ & 29 \\
\hline & $>1$ & 1 & 1 & $0 / 1$ & 34 \\
\hline & $>1$ & $>1$ & 1 & $0 / 1$ & 40 \\
\hline & \multicolumn{4}{|c|}{ Possible circular failure (for very random orientation in soft or very weathered rock) } & 30 \\
\hline \multirow{3}{*}{$\begin{array}{l}\text { Geo-mechanical } \\
\text { (Lithological) }\end{array}$} & \multicolumn{4}{|c|}{ High rock mass strength } & 5 \\
\hline & \multicolumn{4}{|c|}{ Medium rock mass strength } & 7 \\
\hline & \multicolumn{4}{|c|}{ Weak rock mass strength } & 10 \\
\hline \multirow{3}{*}{ Hydro-geological } & \multicolumn{4}{|c|}{ Dry and rain induced } & 5 \\
\hline & \multicolumn{4}{|l|}{ No springs, seeps } & 8 \\
\hline & \multicolumn{4}{|c|}{ Permanent springs and streams } & 10 \\
\hline \multirow{2}{*}{ Seismo-tectonic } & \multicolumn{4}{|c|}{ Minor fault fold axis } & 10 \\
\hline & \multicolumn{4}{|c|}{ Major fault or fold axis } & 20 \\
\hline \multirow{3}{*}{ Land use } & \multicolumn{4}{|l|}{ Forest } & 0 \\
\hline & \multicolumn{4}{|l|}{ Cultivated land } & 5 \\
\hline & \multicolumn{4}{|l|}{ Dry barren land } & 8 \\
\hline \multirow{3}{*}{ Rock slide } & \multicolumn{4}{|l|}{ Rock slide } & 15 \\
\hline & \multicolumn{4}{|l|}{ Tension Crack } & 20 \\
\hline & \multicolumn{4}{|c|}{ Landslide, highly developed gullies } & 30 \\
\hline
\end{tabular}




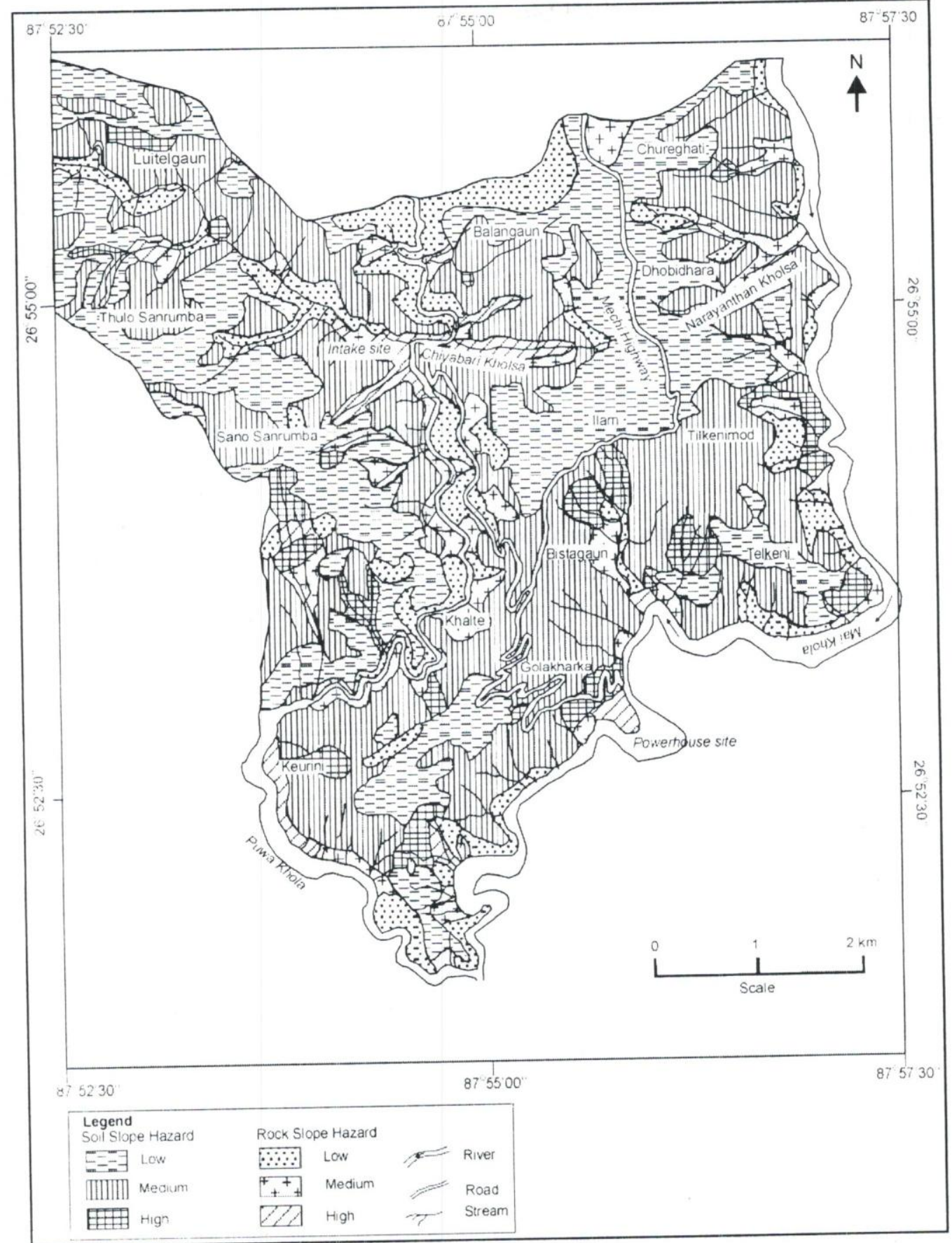

Fig. 9: Hazard map of the Ilam hydropower project and adjacent area.

\section{CONCLUSIONS}

The study area is the southern continuation of the Higher Himalayan Crystalline thrust sheet, which comprises mainly of garnet-kyanite-sillimanite gneisses, schistose gneisses, orthogneiss and coarse-grained white quartzite. Schistose gneiss and banded gneiss are moderate to highly weathered whereas quartzite is slightly weathered. The UCS value for quartzite is $144.48 \mathrm{Mpa}$ but this values for schistose gneiss and banded gneiss are up to $95 \mathrm{Mpa}$ and $118 \mathrm{Mpa}$ respectively. On the basis of joint spacing, the rock masses of the area are graded from crush and scattered to massive. The soils found in the area are alluvial, colluvial and residual, among which the colluvial soil is extensively distributed in the area. Soil depth of the area is controlled by the topography. Deep soil cover was found around ridges and on gentle slope. Among the various soil depth, most of the landslides occurred in 3-6 m depth.

The slope stability of the area has been influenced by land use pattern. It is found that effect of landslide is more in shrub and barren land. The conversion of forest land to 
arable land and shrub land has accelerated hazard and also played important role in the development of slop instability and surface erosion in the study area. Slope angle between $26^{\circ}$ and $40^{\circ}$ found to be more susceptible for landslides. Though several types of mass movements are observed in the area, the translational soil slides are the most common. Large plane rockslides are found on dip slopes whereas wedge failures and topples are common scarp slopes Therefore, the distribution of landslide is related with topography, soil depth, slope, land use pattern, rock type, geological structure and climatic condition.

The landslide hazard mapping is found to be a useful tool for delimiting the areas susceptible to sliding. The main attributing factors for landslide hazards in the study area are slope, land use pattern, rock types and associated discontinuity, soil type, soil depth, etc. The high hazard zones for rock slopes are confined to the steep dip slopes with fractured rocks whereas soil slope hazard is confined to fault zones and south facing slope. The soil slope hazard is more severe than the rock slope. The areas falling low hazard zones are safe zones where normally no natural disaster occur whereas medium hazard region can be made safe and stable with mitigative measures. High hazard zones should better be avoided for development activities.

\section{ACKNOWLEDGEMENTS}

The authors are grateful to Mr Prakash Das Ulak, Lecturer, Department of Geology, Tri-Chandra Campus, Tribhuvan University, and Mr Aniruddha Poudel, Nepal Electricity Authority for their help during preparation of this paper.

\section{REFERENCES}

Auden, J. B., 1935, Transverse in the Himalaya, Rec. Geol. Surv., India, v. 69(2), pp. 123-167.

Chamlagain, D., 2000, Engineering geological and geotechnical study in and around the Ilam Hydropower Project, Far Eastern Nepal, Higher Himalaya, M. Sc. Thesis submitted to the central Department of Geology, Tribhuvan University, Kathmandu, Nepal, 409+p. (Unpublished).

Deoja, B., Dhital, M. R. Thapa, B., and Wagner, A. (eds.), 1991, Mountain Risk Engineering (MRE) Handbook, Part I and II, ICIMOD, Kathmandu, Nepal, 875 p.

Department of Hydrology and Metereology (DHM), 1995/96. Climatological Records of Nepal(1995/96), Ministry of Water Resources, Kathmandu, Nepal.

Gansser, A., 1964, Geology of the Himalayas. Interscience Publisher, London, $289 \mathrm{p}$.

Hoek, E. and Bray, J., 1977, Rock slope engineering. The Institute of Mining and Metallurgy, London, $2^{\text {nd }}$ edition, $402 \mathrm{p}$.

Kayastha, N. B., 1969, The geology of Ilam district in South Eastern Nepal. Department of Mines and Geology, Kathmandu, Nepal, 25 p. (Unpublished. Report).

Le Fort, P., 1975, Himalaya [S]: The collided ranges. present knowledge of the continental arc. American Journal of Science v. $275 \mathrm{~A}$, pp. 1-44

Schelling, D. and Arita, K., 1991, Thrust tectonic, crustal shortening, and the structure of the far eastern Nepal Himalaya. Tectonics, v. 10(5), pp. 851-862.

Schelling, D., 1992, The tectonostratigraphy and structures of the eastern Nepal Himalaya. Tectonics, v. 11(5), pp. 925-943.

Uromeihy, A., 2000, Effects of land use on the development of slope instability in the Neka-Road watershed, Iran. Jour. Nepal. Geol. Soc. (Spec. Issue), v. 22, pp. 421-428. 